\title{
Buffer Additives and Packaging Differentially Influence the Stability of Dyes Commonly Used in Chromovitrectomy
}

\author{
Begoña Parrado Aliod Wilfried Kugler Tim Häring \\ Fluoron $\mathrm{GmbH}$, Ulm, Germany
}

\begin{abstract}
What Is It about?
Staining intraocular membranes has become routine in modern ophthalmic surgery. However, the accuracy of this procedure is directly impacted not only by the dye chosen, but also by the additives and packaging used for the dye. This study found that additives and packaging affect the shelf life of the most commonly used dyes, which can lead to false-positive test results.
\end{abstract}

\section{Keywords}

Chromovitrectomy · Deuterium oxide · D-Mannitol · Polyethylene glycol $3350 \cdot$ Internal limiting membrane staining $\cdot$ Macular holes

\begin{abstract}
Purpose: This study was performed to investigate the chemical stability of different dyes used in chromovitrectomy and the influence of various product parameters on it. Methods: Buffered dye solutions were prepared containing $1.5 \mathrm{~g} / \mathrm{L}$ acid violet $17,0.25 \mathrm{~g} / \mathrm{L}$ brilliant blue $\mathrm{G}, 1.3 \mathrm{~g} / \mathrm{L}$ bromophenol blue, and $1.5 \mathrm{~g} / \mathrm{L}$ trypan blue, combined with deuterium oxide, polyethylene glycol 3350, and D-mannitol as additives. For accelerated storage testing, samples were incubated for $400 \mathrm{~h}$ at $80^{\circ} \mathrm{C}$ corresponding to 2 years according to the Van 't Hoff equation. After different incubation times samples were taken for UV/Vis spectroscopy, $\mathrm{pH}$ measurement, and osmometry. Results: Depending on dye, additive, and packaging, different solutions exhibit differences in chemical stability and hence shelf life. Packaging in syringes instead of vials increases dye stability. Additives may negatively influence important parameters, e.g. polyethylene glycol 3350 increases osmolality beyond the physiological
\end{abstract}

Parts of this paper have been presented as poster at the ARVO 2016 annual meeting in Seattle, WA, USA (\#C0056). 
range. Notably, acid violet 17 is chemically unstable except in D-mannitol-containing buffer, packed in syringes. However, simultaneously, D-mannitol leads to a $\mathrm{pH}$ shift below 7.0. Conclusion: In summary, dye solutions filled in syringes should be preferred to vials to slow down oxidative degradation. Especially acid violet 17 solutions should be used with caution because the addition of $\mathrm{D}$-mannitol may contribute to $\mathrm{pH}$ values beyond the physiological range.

(C) 2016 The Author(s)

Published by S. Karger AG, Basel

\section{Introduction}

The staining of intraocular membranes during vitrectomy, also known as chromovitrectomy, has become a routine application in modern ophthalmic surgery. This method was first described in 2000 by Burk and colleagues using indocyanine green (ICG) as staining agent [1]. However, it has been known for a long time that ICG is quite unstable in aqueous solutions [2] and therefore has to be prepared immediately before use. The degradative reactions of ICG lead to destaining and are irreversible. Thus, uniform staining results are hardly guaranteed [3]. In addition, degradation products of ICG negatively influence biocompatibility [4].

Meanwhile, different dye solutions are commercially available, ready-to-use, and CE marked. These solutions contain dyes such as acid violet 17 (AV), brilliant blue G (BBG), bromophenol blue (BPB), and trypan blue. Importantly, these various products do not only differ from each other with respect to the dye but also in the different additives used as well as in packaging. On the one hand, the various additives used all increase the density of the respective solution. On the other hand, additives differ substantially with respect to their chemistry. In the early years of chromovitrectomy, glucose was the first choice to increase the density of dye solutions. However, due to toxic effects triggered by glucose [5], various alternatives have been developed. Today, 3 different additives are mainly used to increase the density in commercially available dye solutions: deuterium oxide, D-mannitol, and polyethylene glycol. These solutions have an expiry date of at least 2 years. In general, the shelf life of medical devices can be related to different parameters, e.g. warranty of sterility. Otherwise to be used as staining agent, it is equally important to obtain consistent color strength. To this end it has to be guaranteed that the dye does not change chemically during storage. Unfortunately, however, comparative stability studies of the different dyes in aqueous solutions are not available yet.

The aim of this study was to investigate the stability of different dyes as well as the influence of buffer additives and packaging on it. The results obtained reveal that there are differences in stability and hence shelf life depending on dye, additive, and packaging.

\section{Methods}

First, buffer solutions for 4 different dyes used in chromovitrectomy were prepared, identical in composition to commercially available dye solutions. All buffers were based on $8.2 \mathrm{~g} / \mathrm{L}$ sodium chloride $(\mathrm{NaCl}), 1.9 \mathrm{~g} / \mathrm{L}$ disodium hydrogen phosphate dihydrate, and 0.3 $\mathrm{g} / \mathrm{L}$ sodium dihydrogen phosphate dihydrate (all from Carl Roth, Germany), prepared with water for injection (Fresenius Kabi, Germany). As additives, we used $130 \mathrm{~g} / \mathrm{L}$ deuterium oxide (Carl Roth), $49 \mathrm{~g} / \mathrm{L}$ D-mannitol (Amresco, USA), and $40 \mathrm{~g} / \mathrm{L}$ polyethylene glycol 3350 (Sigma Aldrich, USA). Note that $\mathrm{NaCl}$ was omitted from the buffer containing D-mannitol, 


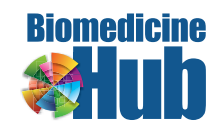

Fig. 1. Percentage of different dyes in phosphate buffer filled in syringes (S) and vials (V) after artificial aging for $400 \mathrm{~h}$ at $80^{\circ} \mathrm{C}$ as determined with UV/Vis spectroscopy. The results shown are means \pm SD $(n=3)$. The level of absorption maximum measured in the unaged samples is referred to as $100 \%$. $\mathrm{AV}$, acid violet 17 ; BBG, brilliant blue G; BPB, bromophenol blue; TB, trypan blue.
Biomed Hub 2016;1:452241 (DOI: 10.1159/000452241)

Parrado Aliod et al.: Buffer Additives and Packaging Differentially Influence the Stability of Dyes Commonly Used in Chromovitrectomy

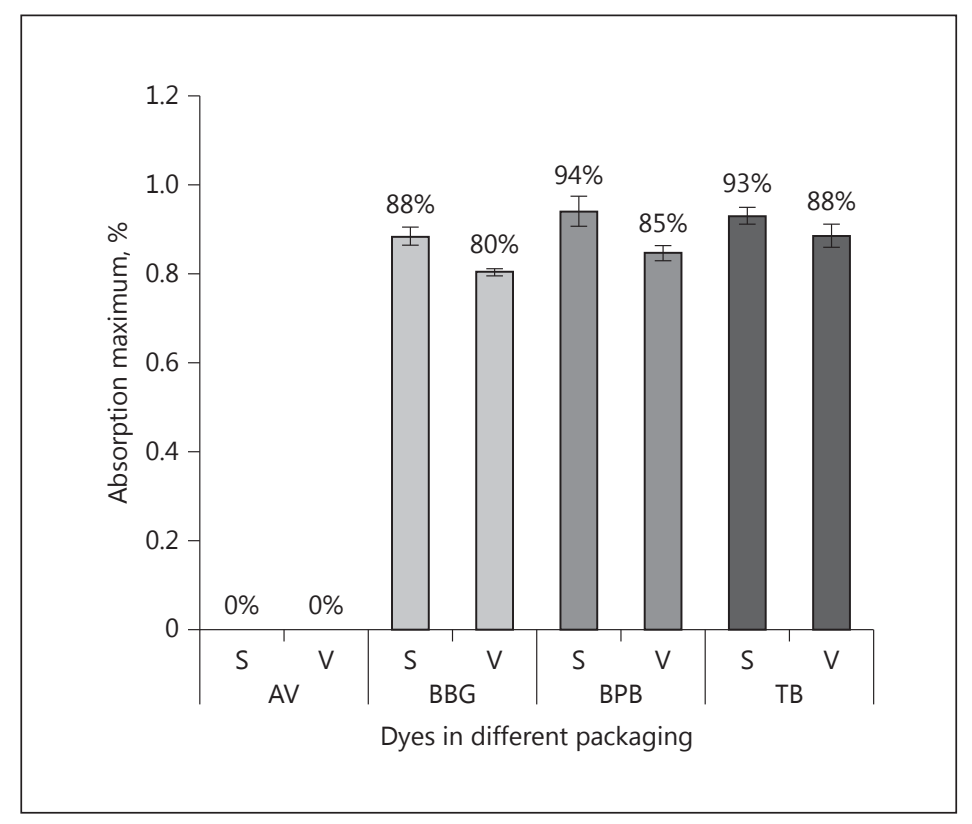

because otherwise a substantial increase in osmolality ( $>500 \mathrm{mosm} / \mathrm{kg}$ ) is observed. In addition, the corresponding product, which was commercially available until recently, also contained no $\mathrm{NaCl}$. These different buffers were used to prepare one of the following dye solutions: $1.5 \mathrm{~g} / \mathrm{L} \mathrm{AV} \mathrm{(Sigma} \mathrm{Aldrich),} 0.25 \mathrm{~g} / \mathrm{L} \mathrm{BBG}$ (Sigma Aldrich), $1.3 \mathrm{~g} / \mathrm{L} \mathrm{BPB}$ (Fluka Analytical, USA), and $1.5 \mathrm{~g} / \mathrm{L}$ trypan blue (Merck, Germany). These concentrations were selected to match commercially available products. Using a $0.2-\mu \mathrm{m}$ sterile filter (Sartorius, Germany), 0.6-mL aliquots of each of the solutions prepared were filled in 2-mL glass vials (Dedecke, Germany) and 1-mL glass syringes (Gerresheimer, Germany) under clean room conditions (ISO 5). All samples were terminally sterilized by autoclaving at $121^{\circ} \mathrm{C}$ for 20 min (Holzner, Germany).

\section{Artificial Aging}

To mimic a storage period of 2 years at $25^{\circ} \mathrm{C}$, the samples under study were incubated for $400 \mathrm{~h}$ at $80^{\circ} \mathrm{C}$ in a heating and drying oven (Memmert, Germany). According to the Van ' $\mathrm{t}$ Hoff equation an increase in temperature by $10 \mathrm{~K}$ will lead to doubling of the reaction rate. Applying this rule, $400 \mathrm{~h}$ at $80^{\circ} \mathrm{C}$ equate approximately to $18,000 \mathrm{~h}$ at $25^{\circ} \mathrm{C}$, which corresponds to 2 years. After 100, 200, 300, and $400 \mathrm{~h}$ of incubation, samples were taken for analysis.

\section{Dye Quantification}

The amount of dye was determined by UV/Vis spectroscopy (Thermo Scientific, USA). To identify the dye-specific dilution, which results in a peak height within the effective range (1-2.5 absorption units), different dilutions of the unaged dye solutions were tested. Having identified a suitable dilution for each dye under study, this parameter was used in all subsequent measurements. Before starting artificial aging of the different dye solutions, a corresponding probe was measured as unaged reference. All the other samples were measured directly at the end of artificial aging. Data of absorption maxima were normalized as a percentage of the value of the corresponding unaged dye solution, arbitrarily defined as $100 \%$. Data are expressed as means \pm SD, $n=3$ from separate samples. 


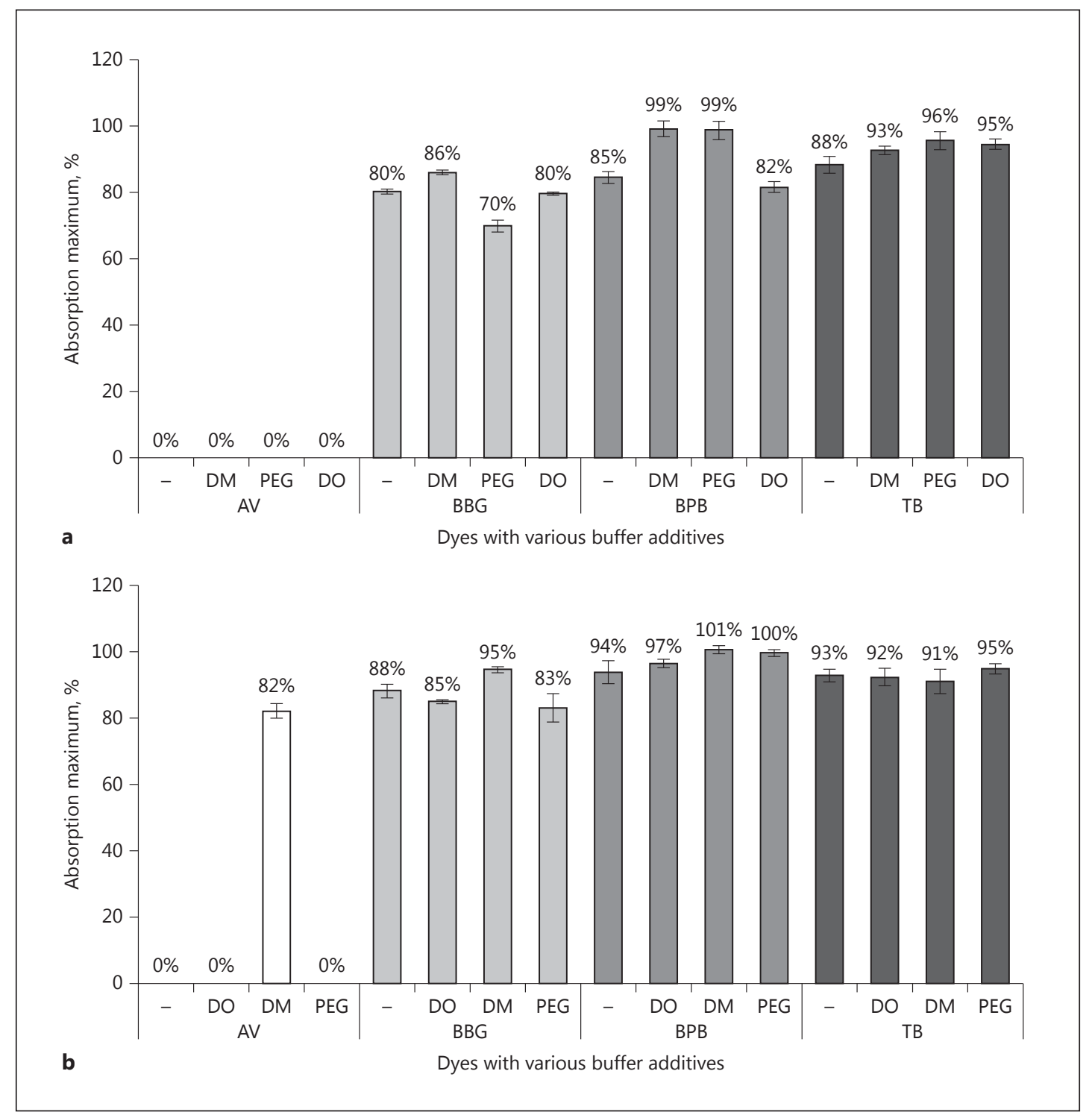

Fig. 2. Percentage of different dyes in phosphate buffer containing commercially available additives filled in vials (a) and syringes (b) after artificial aging for $400 \mathrm{~h}$ at $80^{\circ} \mathrm{C}$ as determined with UV/Vis spectroscopy. The results shown are means $\pm \mathrm{SD}(n=3)$. The level of absorption maximum measured in the unaged samples is referred to as $100 \%$. AV, acid violet 17 ; $\mathrm{BBG}$, brilliant blue $\mathrm{G}$; $\mathrm{BPB}$, bromophenol blue; TB, trypan blue; DO, deuterium oxide; DM, D-mannitol; PEG, polyethylene glycol 3350.

\section{pH Value}

All $\mathrm{pH}$ determinations were performed using a $\mathrm{pH}$ meter (WTW, Germany) calibrated at pH 7.01 and 10.0 on each day the measurements were taken. Data are expressed as means \pm $\mathrm{SD}, n=3$ from separate samples.

\section{Osmolality}

All osmolality determinations were performed using a freezing-point depression osmometer (Knauer, Germany) calibrated at 0 and $400 \mathrm{mosm} / \mathrm{kg}$ on each day the measurements were taken. Data are expressed as means $\pm \mathrm{SD}, n=3$ from separate samples. 
(c) 2016 The Author(s). Published by S. Karger AG, Basel www.karger.com/bmh

Parrado Aliod et al.: Buffer Additives and Packaging Differentially Influence the Stability of Dyes Commonly Used in Chromovitrectomy

Table 1. Time course of absorption units of different dye/buffer combinations filled in syringes during artificial aging at $80^{\circ} \mathrm{C}(n=3)$

\begin{tabular}{|c|c|c|c|c|c|}
\hline Dye & $\begin{array}{l}\text { Buffer/artificial } \\
\text { aging at } 80^{\circ} \mathrm{C}, \mathrm{h}\end{array}$ & PB & $+\mathrm{DO}$ & + PEG & $+\mathrm{DM}$ \\
\hline \multicolumn{6}{|c|}{ Absorption at $584 \mathrm{~nm}$} \\
\hline \multirow[t]{5}{*}{ BBG } & 0 & $1.045(100 \%)$ & $1.131(100 \%)$ & $1.077(100 \%)$ & $1.095(100 \%)$ \\
\hline & 100 & $1.038(99 \%)$ & $1.068(94 \%)$ & $0.991(92 \%)$ & $1.067(97 \%)$ \\
\hline & 200 & $1.023(98 \%)$ & $1.000(88 \%)$ & $0.915(85 \%)$ & $1.080(99 \%)$ \\
\hline & 300 & $0.975(93 \%)$ & $1.026(91 \%)$ & $0.937(87 \%)$ & $1.063(97 \%)$ \\
\hline & 400 & $0.923(88 \%)$ & $0.963(85 \%)$ & $0.897(83 \%)$ & $1.038(95 \%)$ \\
\hline \multicolumn{6}{|c|}{ Absorption at $590 \mathrm{~nm}$} \\
\hline \multirow[t]{5}{*}{$\mathrm{BPB}$} & 0 & $2.211(100 \%)$ & $2.220(100 \%)$ & $2.246(100 \%)$ & $2.241(100 \%)$ \\
\hline & 100 & $2.164(98 \%)$ & $2.255(102 \%)$ & $2.279(101 \%)$ & $2.252(100 \%)$ \\
\hline & 200 & $2.142(97 \%)$ & $2.243(101 \%)$ & $2.276(101 \%)$ & $2.272(101 \%)$ \\
\hline & 300 & $2.072(94 \%)$ & $2.168(98 \%)$ & $2.305(102 \%)$ & $2.252(101 \%)$ \\
\hline & 400 & $2.076(94 \%)$ & $2.144(97 \%)$ & $2.242(100 \%)$ & $2.259(101 \%)$ \\
\hline \multicolumn{6}{|c|}{ Absorption at $586 \mathrm{~nm}$} \\
\hline \multirow[t]{5}{*}{ TB } & 0 & $1.270(100 \%)$ & $1.270(100 \%)$ & $1.268(100 \%)$ & $1.172(100 \%)$ \\
\hline & 100 & $1.179(93 \%)$ & $1.179(94 \%)$ & $1.228(97 \%)$ & $1.114(95 \%)$ \\
\hline & 200 & $1.174(92 \%)$ & $1.174(92 \%)$ & $1.204(95 \%)$ & $1.079(92 \%)$ \\
\hline & 300 & $1.173(92 \%)$ & $1.173(92 \%)$ & $1.197(94 \%)$ & $1.114(95 \%)$ \\
\hline & 400 & $1.180(93 \%)$ & $1.180(92 \%)$ & $1.204(95 \%)$ & $1.068(91 \%)$ \\
\hline \multicolumn{6}{|c|}{ Absorption at $544 \mathrm{~nm}$} \\
\hline \multirow[t]{5}{*}{$\mathrm{AV}$} & 0 & $1.809(100 \%)$ & $1.752(100 \%)$ & $1.736(100 \%)$ & $2.066(100 \%)$ \\
\hline & 100 & $0.000(0 \%)$ & $0.000(0 \%)$ & $0.000(0 \%)$ & $1.849(90 \%)$ \\
\hline & 200 & $0.000(0 \%)$ & $0.000(0 \%)$ & $0.000(0 \%)$ & $1.674(81 \%)$ \\
\hline & 300 & $0.000(0 \%)$ & $0.000(0 \%)$ & $0.000(0 \%)$ & $1.664(81 \%)$ \\
\hline & 400 & $0.000(0 \%)$ & $0.000(0 \%)$ & $0.000(0 \%)$ & $1.702(82 \%)$ \\
\hline
\end{tabular}

$\mathrm{AV}$, acid violet 17; BBG, brilliant blue G; BPB, bromophenol blue; TB, trypan blue; PB, phosphate buffer; DO, deuterium oxide; DM, D-mannitol; PEG, polyethylene glycol 3350.

\section{Results}

To get an impression how the various dye solutions differ in stability, we first analyzed the percentage of dye after storage for $400 \mathrm{~h}$ at $80^{\circ} \mathrm{C}$ compared to the amount of dye before starting the aging process. Figure 1 shows that after $400 \mathrm{~h}$ at $80^{\circ} \mathrm{C}, \mathrm{BBG}, \mathrm{BPB}$, and trypan blue exhibit residual concentrations between 80 and $90 \%$. Obviously, they are subjected to only minor degradation. In contrast to these 3 dyes, AV is totally degraded. Interestingly, this degradation is already visually observable. The color of the dye solution changes from dark violet to light green. Thus, our present data indicate that dye solutions containing AV in phosphate-buffered saline may be rather unstable.

Second, we determined the influence of packaging on the stability of the different dye solutions. The results demonstrate that dye solutions filled in syringes are much more stable than in vials (Fig. 1). Again, this observation applies to all dyes except AV. This dye is degraded independent of packaging.

Third, we wanted to test the influence of standard buffer additives, deuterium oxide, D-mannitol, and polyethylene glycol 3350, on dye stability. The results revealed different findings. For example, in combination with PEG, BBG exhibits its poorest stability, whereas the stability of BPB is $>98 \%$. Irrespective of the additive used there is no AV detectable in 
Table 2. Time course of absorption units of different dye/buffer combinations filled in vials during artificial aging at $80^{\circ} \mathrm{C}(n=3)$

\begin{tabular}{|c|c|c|c|c|c|}
\hline Dye & $\begin{array}{l}\text { Buffer/artificial } \\
\text { aging at } 80^{\circ} \mathrm{C}, \mathrm{h}\end{array}$ & PB & $+\mathrm{DO}$ & $+\mathrm{PEG}$ & $+\mathrm{DM}$ \\
\hline \multicolumn{6}{|c|}{ Absorption at $584 \mathrm{~nm}$} \\
\hline \multirow[t]{5}{*}{ BBG } & 0 & $0.999(100 \%)$ & $1.077(100 \%)$ & $1.021(100 \%)$ & $1.028(100 \%)$ \\
\hline & 100 & $0.936(94 \%)$ & $0.943(88 \%)$ & $0.921(90 \%)$ & $1.006(98 \%)$ \\
\hline & 200 & $0.878(88 \%)$ & $0.902(84 \%)$ & $0.822(81 \%)$ & $0.941(92 \%)$ \\
\hline & 300 & $0.808(81 \%)$ & $0.886(82 \%)$ & $0.784(77 \%)$ & $0.921(90 \%)$ \\
\hline & 400 & $0.801(80 \%)$ & $0.856(80 \%)$ & $0.713(70 \%)$ & $0.884(86 \%)$ \\
\hline \multicolumn{6}{|c|}{ Absorption at $590 \mathrm{~nm}$} \\
\hline \multirow[t]{5}{*}{ ВРB } & 0 & $2.175(100 \%)$ & $2.241(100 \%)$ & $2.230(100 \%)$ & $2.233(100 \%)$ \\
\hline & 100 & $2.140(98 \%)$ & $2.193(98 \%)$ & $2.276(102 \%)$ & $2.264(101 \%)$ \\
\hline & 200 & $2.033(93 \%)$ & $2.050(91 \%)$ & $2.234(100 \%)$ & $2.286(102 \%)$ \\
\hline & 300 & $1.957(90 \%)$ & $2.004(89 \%)$ & $2.248(101 \%)$ & $2.308(103 \%)$ \\
\hline & 400 & $1.839(85 \%)$ & $1.828(82 \%)$ & $2.200(99 \%)$ & $2.213(99 \%)$ \\
\hline \multicolumn{6}{|c|}{ Absorption at $586 \mathrm{~nm}$} \\
\hline \multirow[t]{5}{*}{ TB } & 0 & $1.281(100 \%)$ & $1.256(100 \%)$ & $1.286(100 \%)$ & $1.182(100 \%)$ \\
\hline & 100 & $1.148(90 \%)$ & $1.227(98 \%)$ & $1.199(93 \%)$ & $1.145(97 \%)$ \\
\hline & 200 & $1.159(90 \%)$ & $1.176(94 \%)$ & $1.209(94 \%)$ & $1.105(93 \%)$ \\
\hline & 300 & $1.181(92 \%)$ & $1.172(93 \%)$ & $1.174(91 \%)$ & $1.128(95 \%)$ \\
\hline & 400 & $1.133(88 \%)$ & $1.187(95 \%)$ & $1.230(96 \%)$ & $1.096(93 \%)$ \\
\hline \multicolumn{6}{|c|}{ Absorption at $544 \mathrm{~nm}$} \\
\hline \multirow[t]{5}{*}{ AV } & 0 & $1.399(100 \%)$ & $0.942(100 \%)$ & $0.999(100 \%)$ & $1.659(100 \%)$ \\
\hline & 100 & $0.000(0 \%)$ & $0.000(0 \%)$ & $0.000(0 \%)$ & $0.000(0 \%)$ \\
\hline & 200 & $0.000(0 \%)$ & $0.000(0 \%)$ & $0.000(0 \%)$ & $0.000(0 \%)$ \\
\hline & 300 & $0.000(0 \%)$ & $0.000(0 \%)$ & $0.000(0 \%)$ & $0.000(0 \%)$ \\
\hline & 400 & $0.000(0 \%)$ & $0.000(0 \%)$ & $0.000(0 \%)$ & $0,000(0 \%)$ \\
\hline
\end{tabular}

$\mathrm{AV}$, acid violet 17; BBG, brilliant blue G; BPB, bromophenol blue; TB, trypan blue; PB, phosphate buffer; DO, deuterium oxide; DM, D-mannitol; PEG, polyethylene glycol 3350.

vials. Strikingly, only the combination of AV with D-mannitol filled in syringes stabilized AV (Fig. 2a, b).

Tables 1 and 2 summarize the absorption values obtained after different times of artificial aging of various dye/buffer combinations. Depending on dye, additive, and packaging, the data clearly show significant differences in absorption values and hence in stability and thus shelf life.

The last 2 experimental series analyzed the variation of 2 physiologically important parameters, $\mathrm{pH}$ and osmolality, during aging. Our results obtained so far revealed that AV, filled in vials, is subjected to the strongest changes. Figure 3 clearly shows that all AV/buffer combinations ensure stable $\mathrm{pH}$ values between 7.0 and 7.4 over time, except the D-mannitol-containing $\mathrm{AV}$ solution. In the latter case the $\mathrm{pH}$ drops below 7.0, already detectable after $100 \mathrm{~h}$ of incubation, which roughly equals a storage time of 6 months at $25^{\circ} \mathrm{C}$. Values below pH 7.0 were also observed in other dye/buffer combinations filled in vials and syringes, but only if D-mannitol was used as additive (Tables 3,4 ).

Analysis of changes in osmolality during the time of aging revealed no meaningful differences among the different dyes. In general, the osmolality of all dye solutions increases over time and is beyond the physiological range of $280-300 \mathrm{mosm} / \mathrm{kg}$. This is most prominent in 


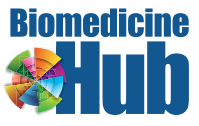

Table 3. Time course of $\mathrm{pH}$ values of different dye/buffer combinations filled in vials during artificial aging at $80^{\circ} \mathrm{C}$ $(n=3)$

\begin{tabular}{|c|c|c|c|c|c|}
\hline \multicolumn{6}{|c|}{ Biomed Hub 2016;1:452241 (DOI: 10.1159/000452241) } \\
\hline \multicolumn{6}{|c|}{$\begin{array}{l}\text { (c) } 2016 \text { The Author(s). Published by S. Karger AG, Basel } \\
\text { www.karger.com/bmh }\end{array}$} \\
\hline \multicolumn{6}{|c|}{$\begin{array}{l}\text { Parrado Aliod et al.: Buffer Additives and Packaging Differentially Influence the } \\
\text { Stability of Dyes Commonly Used in Chromovitrectomy }\end{array}$} \\
\hline \multirow[t]{2}{*}{ Dye } & \multirow{2}{*}{$\begin{array}{l}\text { Buffer/artificial } \\
\text { aging at } 80^{\circ} \mathrm{C}, \mathrm{h}\end{array}$} & \multicolumn{4}{|c|}{$\mathrm{pH}$ value } \\
\hline & & $\mathrm{PB}$ & $+\mathrm{DO}$ & +PEG & $+\mathrm{DM}$ \\
\hline \multirow[t]{5}{*}{$B B G$} & 0 & 7.58 & 7.61 & 7.60 & 7.50 \\
\hline & 100 & 7.54 & 7.54 & 7.54 & 7.30 \\
\hline & 200 & 7.60 & 7.61 & 7.57 & 7.27 \\
\hline & 300 & 7.63 & 7.64 & 7.54 & 7.26 \\
\hline & 400 & 7.61 & 7.59 & 7.53 & 7.19 \\
\hline \multirow[t]{5}{*}{ BPB } & 0 & 7.35 & 7.38 & 7.46 & 6.94 \\
\hline & 100 & 7.26 & 7.32 & 7.41 & 6.90 \\
\hline & 200 & 7.19 & 7.26 & 7.40 & 6.92 \\
\hline & 300 & 7.17 & 7.24 & 7.39 & 6.91 \\
\hline & 400 & 7.09 & 7.15 & 7.33 & 6.90 \\
\hline \multirow[t]{5}{*}{ ТВ } & 0 & 7.49 & 7.53 & 7.57 & 7.48 \\
\hline & 100 & 7.48 & 7.50 & 7.54 & 7.30 \\
\hline & 200 & 7.50 & 7.51 & 7.56 & 7.25 \\
\hline & 300 & 7.50 & 7.51 & 7.56 & 7.21 \\
\hline & 400 & 7.45 & 7.49 & 7.53 & 7.16 \\
\hline \multirow[t]{5}{*}{ AV } & 0 & 7.35 & 7.42 & 7.43 & 7.24 \\
\hline & 100 & 7.13 & 7.26 & 7.16 & 6.76 \\
\hline & 200 & 7.14 & 7.28 & 7.23 & 6.70 \\
\hline & 300 & 7.21 & 7.35 & 7.20 & 6.68 \\
\hline & 400 & 7.18 & 7.28 & 7.21 & 6.59 \\
\hline
\end{tabular}

$\mathrm{AV}$, acid violet 17; BBG, brilliant blue G; $\mathrm{BPB}$, bromophenol blue; TB, trypanblue; $\mathrm{PB}$, phosphate buffer; DO, deuterium oxide; DM, D-mannitol; PEG, polyethylene glycol 3350.
Fig. 3. Time course of $\mathrm{pH}$ values of acid violet 17 in phosphate buffer containing different additives filled in vials during artificial aging at $80^{\circ} \mathrm{C}$. The results shown are means $(n=3)$. For clarity, indication of \pm SD was omitted. Values of $\mathrm{pH} 7.8$ and 7.0 were set as upper and lower physiological limits, respectively (dashed lines). DO, deuterium oxide; DM, D-mannitol; PEG, polyethylene glycol 3350 . 


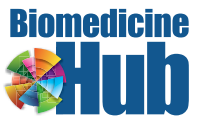

Table 4. Time course of $\mathrm{pH}$ values of different dye/buffer combinations filled in syringes during artificial aging at $80^{\circ} \mathrm{C}$ $(n=3)$
Biomed Hub 2016;1:452241 (DOI: 10.1159/000452241)

(C) 2016 The Author(s). Published by S. Karger AG, Basel www.karger.com/bmh

Parrado Aliod et al.: Buffer Additives and Packaging Differentially Influence the Stability of Dyes Commonly Used in Chromovitrectomy

\begin{tabular}{|c|c|c|c|c|c|}
\hline \multirow[t]{2}{*}{ Dye } & \multirow{2}{*}{$\begin{array}{l}\text { Buffer/artificial } \\
\text { aging at } 80^{\circ} \mathrm{C}, \mathrm{h}\end{array}$} & \multicolumn{4}{|c|}{$\mathrm{pH}$ value } \\
\hline & & PB & $+\mathrm{DO}$ & $+\mathrm{PEG}$ & $+\mathrm{DM}$ \\
\hline \multirow[t]{5}{*}{ BBG } & 0 & 7.34 & 7.37 & 7.41 & 7.56 \\
\hline & 100 & 7.26 & 7.29 & 7.30 & 7.05 \\
\hline & 200 & 7.23 & 7.28 & 7.28 & 6.92 \\
\hline & 300 & 7.21 & 7.25 & 7.25 & 6.84 \\
\hline & 400 & 7.19 & 7.23 & 7.23 & 6.77 \\
\hline \multirow[t]{5}{*}{ BPB } & 0 & 7.20 & 7.24 & 7.26 & 6.98 \\
\hline & 100 & 7.13 & 7.17 & 7.20 & 6.89 \\
\hline & 200 & 7.09 & 7.15 & 7.22 & 6.87 \\
\hline & 300 & 7.06 & 7.10 & 7.16 & 6.84 \\
\hline & 400 & 7.01 & 7.07 & 7.14 & 6.83 \\
\hline \multirow[t]{5}{*}{ TB } & 0 & 7.33 & 7.36 & 7.38 & 7.52 \\
\hline & 100 & 7.23 & 7.25 & 7.29 & 7.06 \\
\hline & 200 & 7.23 & 7.23 & 7.27 & 7.01 \\
\hline & 300 & 7.18 & 7.20 & 7.25 & 7.05 \\
\hline & 400 & 7.16 & 7.18 & 7.22 & 7.03 \\
\hline \multirow[t]{5}{*}{$\mathrm{AV}$} & 0 & 7.32 & 7.35 & 7.35 & 7.44 \\
\hline & 100 & 7.03 & 7.04 & 7.03 & 6.89 \\
\hline & 200 & 7.02 & 7.02 & 7.00 & 6.79 \\
\hline & 300 & 7.00 & 6.99 & 6.99 & 6.67 \\
\hline & 400 & 6.98 & 7.00 & 6.98 & 6.59 \\
\hline
\end{tabular}

$\mathrm{AV}$, acid violet 17; $\mathrm{BBG}$, brilliant blue G; $\mathrm{BPB}$, bromophenol blue; $\mathrm{TB}$, trypanblue; $\mathrm{PB}$, phosphate buffer; DO, deuterium oxide; DM, D-mannitol; PEG, polyethylene glycol 3350.

\section{Discussion}

In this study, we analyzed the influence of additives and packaging on the stability of different dye solutions used by ophthalmic surgeons during chromovitrectomy. The results of our analyses suggest that, with respect to stability, dye solutions filled in syringes should be preferred to solutions filled in vials. One possible explanation for the greater dye stability demonstrated in syringes is that both the total amount of air and the contact area between dye solution and air is smaller in prefilled syringes. Hence, oxidation processes, which are probably responsible for degradation of the dyes, are slowed down.

Any influence of additives on dye stability could clearly be detected only in the combination of AV and D-mannitol. Interestingly, BBG and BPB also exhibit the highest dye stability in combination with this sugar alcohol. Chemically, all 3 dyes are so-called triarylmethane dyes. The fact that addition of D-mannitol contributes to the stability of the dyes is further evidence that the degradation observed is due to oxidation. It is well known that D-mannitol exhibits antioxidative effects. For example, Liu et al. [6] showed that addition of D-mannitol increases viability after incubation of cells with hydrogen peroxide, a strong oxidant.

Our in vitro results obtained with $\mathrm{AV}$ in combination with D-mannitol, i.e. incidence of degradation products, drop in $\mathrm{pH}$, may contribute to the explanation of the reported clinical adverse effects in $\mathrm{AV}$-assisted peeling of the internal limiting membrane, in particular in patients with macular holes [7]. Another additional reason might be the concentration of the AV solution which was commercially available until recently. This concentration $(1.5 \mathrm{~g} / \mathrm{L})$ is more than 10 times the recommended concentration (up to $0.125 \mathrm{~g} / \mathrm{L}$ ) based on data with the isolated superfused vertebrate retina model [8]. This study was performed at $30^{\circ} \mathrm{C}$, be- 


\section{Blomenticiche 尌任h}

Fig. 4. Osmolality of acid violet 17 in phosphate buffer containing different additives filled in vials before and after artificial aging for $400 \mathrm{~h}$ at $80^{\circ} \mathrm{C}$. The results shown are means $\pm \mathrm{SD}(n=3)$. DO, deuterium oxide; DM, D-mannitol; PEG, polyethylene glycol 3350.

Fig. 5. Osmolality of different dye solutions filled in vials (a) and syringes (b) after artificial aging for $400 \mathrm{~h}$ at $80^{\circ} \mathrm{C}$. The results shown are means $\pm \mathrm{SD}(n=3)$. AV, acid violet 17; BBG, brilliant blue G; $\mathrm{BPB}$, bromophenol blue; TB, trypan blue; DO, deuterium oxide; DM, D-mannitol; PEG, polyethylene glycol 3350.
Biomed Hub 2016;1:452241 (DOI: 10.1159/000452241)

(C) 2016 The Author(s). Published by S. Karger AG, Basel www.karger.com/bmh

Parrado Aliod et al.: Buffer Additives and Packaging Differentially Influence the Stability of Dyes Commonly Used in Chromovitrectomy
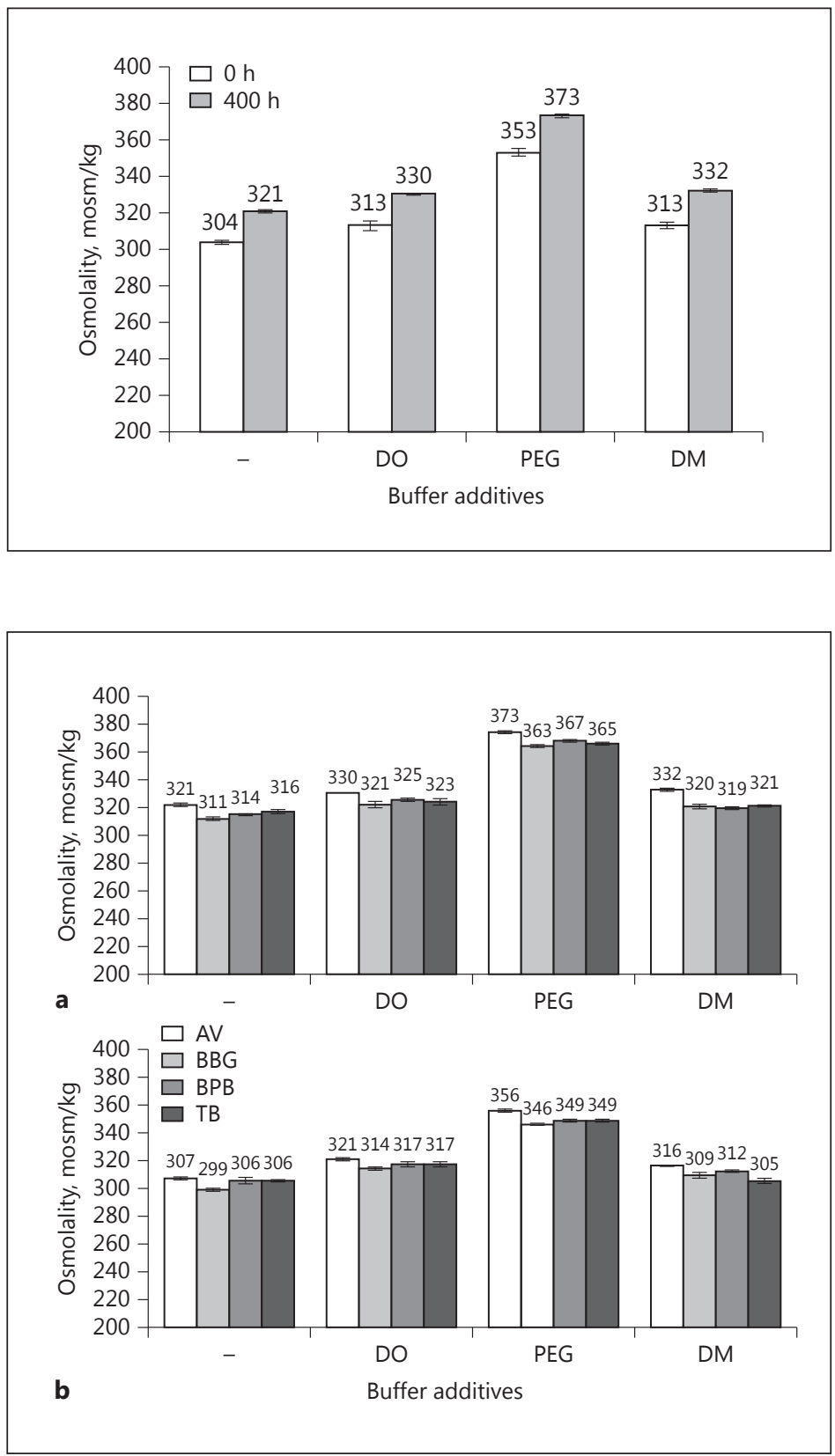

cause at $37^{\circ} \mathrm{C}$ acidic metabolites form [M. Lüke, pers. commun.]. Interestingly, in these experiments the dye was partially retained in the nerve fiber layer and was readily discernible despite the repeated washing steps and the overnight recovery in culture medium. Also, in experiments using the standard ISO 10993 norm test, AV concentrations of $0.75 \mathrm{~g} / \mathrm{L}$ showed clear cytotoxic effects to L929 cells, i.e. leading to cell growth inhibition of more than $30 \%$ [own unpubl. results]. In summary, our data show convincingly that after 2 years, there are differences in stability and hence shelf life of various commercially available dye solutions depending on dye, additive, and packaging. Different buffer additives may negatively influence physiological parameters irrespective of the dye under study. D-mannitol leads to a drastic decrease in $\mathrm{pH}(<7.0)$, and PEG increases osmolality to a critical level of $>370 \mathrm{mosm} / \mathrm{kg}$. 
In the case of $\mathrm{AV}$, only the combination of D-mannitol buffer and packing in syringes shows a relatively high stability. However, this stability is at the expense of a pH shift to the nonphysiological range. Importantly, packing and subsequent clinical use of AV in vials may be extremely critical because no way was shown to stop the degradation of AV.

It might be said that in our study absorption is synonymous with the existence of the undegraded dye. Thus, degradation products exhibiting a comparable absorption spectrum may lead to false positive results. Our data warrant further investigations whether these modifications of the chemical properties do indeed lead to impairment in biocompatibility.

\section{Disclosure Statement}

All authors are employees of Fluoron GmbH.

\section{References}

1 Burk SE, Da Mata AP, Snyder ME, Rosa RH Jr, Foster RE: Indocyanine green-assisted peeling of the retinal internal limiting membrane. Ophthalmology 2000;107:2010-2014.

-2 Gathje J, Steuer RR, Nicholes KR: Stability studies on indocyanine green dye. J Appl Physiol 1970;29:181-185.

-3 Saxena V, Sadoqi M, Shao J: Degradation kinetics of indocyanine green in aqueous solution. J Pharm Sci 2003; 92:2090-2097.

4 Engel E, Schraml R, Maisch T, Kobuch K, König B, Szeimies RM, Hillenkamp J, Bäumler W, Vasold R: Lightinduced decomposition of indocyanine green. Invest Ophthalmol Vis Sci 2008;49:1777-1783.

-5 Haritoglou C, Gandorfer A, Gass CA, Kampik A: Histology of the vitreoretinal interface after staining of the internal limiting membrane using glucose $5 \%$ diluted indocyanine and infracyanine green. Am J Ophthalmol 2004;137:345-348.

-6 Liu JH, Chen MM, Huang JW, Wann H, Ho LK, Pan WH, Chen YC, Liu CM, Yeh MY, Tsai SK, Young MS, Ho LT, Kuo CD, Chuang HY, Chao FP, Chao HM: Therapeutic effects and mechanisms of action of mannitol during $\mathrm{H}_{2} \mathrm{O}_{2}$ induced oxidative stress in human retinal pigment epithelium cells. J Ocul Pharmacol Ther 2010;26:249-257.

7 Gerding H: Acid Violet 17: a new dye for chromovitrectomy? Klin Monbl Augenheilkd 2016;233:460-464.

$>8$ Tura A, Alt A, Haritoglou C, Meyer CH, Schneider T, Grisanti S, Lüke J, Lüke M; International Chromovitrectomy Collaboration: Testing the effects of the dye acid violet-17 on retinal function for an intraocular application in vitreo-retinal surgery. Graefes Arch Clin Exp Ophthalmol 2014;252:1927-1937. 